"Measuring the customer satisfaction based on SERVQUAL model (case study: Mellat Bank in Tehran city)"

\begin{tabular}{|c|c|c|}
\hline AUTHORS & $\begin{array}{l}\text { Nasrin Oskooii } \\
\text { Ebrahim Albonaiemi }\end{array}$ & \\
\hline ARTICLE INFO & $\begin{array}{l}\text { Nasrin Oskooii and Ebrahim Alb } \\
\text { satisfaction based on SERVQU } \\
\text { city). Innovative Marketing , } 13(2\end{array}$ & $\begin{array}{l}\text { easuring the customer } \\
\text { dy: Mellat Bank in Tehran } \\
11 / \text { im.13(2).2017.02 }\end{array}$ \\
\hline DOI & http://dx.doi.org/10.21511/im.13( & \\
\hline RELEASED ON & Wednesday, 12 July 2017 & \\
\hline RECEIVED ON & Sunday, 04 June 2017 & \\
\hline ACCEPTED ON & Monday, 26 June 2017 & \\
\hline LICENSE & $\begin{array}{l}(c) \text { EY } \\
\text { This work is licensed under a Cr } \\
\text { License }\end{array}$ & ttribution 4.0 International \\
\hline JOURNAL & "Innovative Marketing " & \\
\hline ISSN PRINT & $1814-2427$ & \\
\hline ISSN ONLINE & $1816-6326$ & \\
\hline PUBLISHER & LLC "Consulting Publishing Con & erspectives" \\
\hline FOUNDER & LLC "Consulting Publishing Con & erspectives" \\
\hline$\sigma^{0}$ & 15 & $\begin{array}{l}\text { ニニミ } \\
\text { ニ泣 }\end{array}$ \\
\hline NUMBER OF REFERENCES & NUMBER OF FIGURES & NUMBER OF TABLES \\
\hline 22 & 4 & 23 \\
\hline
\end{tabular}

(c) The author(s) 2022. This publication is an open access article. 
Nasrin Oskooii (Iran), Ebrahim Albonaiemi (Iran)

\title{
Measuring the customer satisfaction based on SERVQUAL model (case study: Mellat Bank in Tehran city)
}

\begin{abstract}
Today marketers seek the ways and information to create loyal customers, because it reduces the marketing and operations costs and increases the benefits. In every organization, whether manufacturing or service, customers is the most important factor of ensuring the survival of organization. If the organization succeeds in attracting customers and creating their loyalty, the field of its growth and long term survival can be provided. It is possible to achieve this through studying and planning by management, and this will lead at the end to the comprehensive recognition of customer needs. Since focusing on factors of customers' satisfaction has a significant effect in banking, so, identifying the categories and priorities of these factors are important. All hypotheses of this study are approved both by Student's t-test and Friedman test. The results of study indicated that the factors of reliability, accountability and credit factors, respectively, have more importance in order of priority. In credit factors: variety of banking services (providing any kind of services which customers need); in accountability factors: speed in providing banking services; in reliability factors: proper behavior of staff is considered of the most priority.
\end{abstract}

Keywords: satisfaction, SERVQUAL model, customer loyalty.

JEL Classification: M19.

Received on: $4^{\text {th }}$ of June, 2017.

Accepted on: $26^{\text {th }}$ of June, 2017.

\section{Introduction}

Changes in business environments are occurring very fast. The main challenge of organization managers in present conditions is continuous changes in customers' expectations and needs. Therefore, these managers should always consider this subject that "workplaces are changed and there is a need for new models and procedures to overcome these changes" here that traditional thoughts are not capable and new paradigm of marketing will be formed.

\section{Expressing problem}

Decades ago, banks didn't show much concern about their customers, as almost much of the markets were growing. But today, they found that profitability is possible through attracting the customers and market share (Jonaidi, 2006). In current conditions in which severe competition is formed in country's banking industry, the banks, apart from keeping their customers, should look for new ones who guarantee bank's benefits and also can attract their resources. In this way, banks should pay attention to marketing, so that they by identifying and performing the procedures can achieve their goals. On the other hand, the ethics and social responsibility are also among the important components in predictability to develop, they are considered a part of bank performance, so that projecting this responsibility can be an answer

(c) Limited Liability Company "Consulting Publishing Company "Business Perspectives", 2017.

Nasrin Oskooii, Faculty of Business Management, Persian Gulf International Branch, Islamic Azad University, Khorramshahr, Iran. Ebrahim Albonaiemi, Assistant Professor, Faculty of Business Management, Islamic Azad University, Khorramshahr, Iran. to the environmental needs and challenges, which arise of economic, scientific and technological evolutions in society (Akhavan Serf et al., 2009). Today, the industry of financial services and banking is facing with rapid and unpredictable changes. It is possible only during one month due to economic and political crisis, large banks facing with bankrupcy worldwide and credit markets beeing exposed to depression that resulted in investors toward security of funds and their shares in banks, and, if financial and economic crisis continue, the degree of not believing can't be predicted. Therefore, in regard to accelerating and unpredictable evolutions in today's world, it's not reasonable to employ the past strategies and incompatibility with current situations, which, in turn, causes the weakness of bank against other competitors. Therefore, the banks should also focus on customers like other enterprises and, by detecting long-term objects, make a positive image of themselves in customers' views (Shah Rajabian, 2009).

\subsection{The goals of investigation.}

- Making loyal and enhancing the bank's customer's share.

- Developing and expanding the market.

- Returning and enabling the relationship with customers.

\subsection{Concept of customer's satisfaction.} Understanding how to form positive and negative attitudes of customers toward services and their influence on purchase behavior is a basic theoretical problem (Davis, Moutinho, 1996). Customer satisfaction is an introduction to keep the customer and customer loyalty, which lead to achieving 
such economic goals as profitability, market share and return on assets (ROA). What is the customer satisfaction equation? The simplest model is as follows:

$$
\mathrm{P}=\mathrm{p} \text { e }
$$

Performance - expectations

Fig. 1. The customer satisfaction equation

Different situations will be formed in the following conditions:

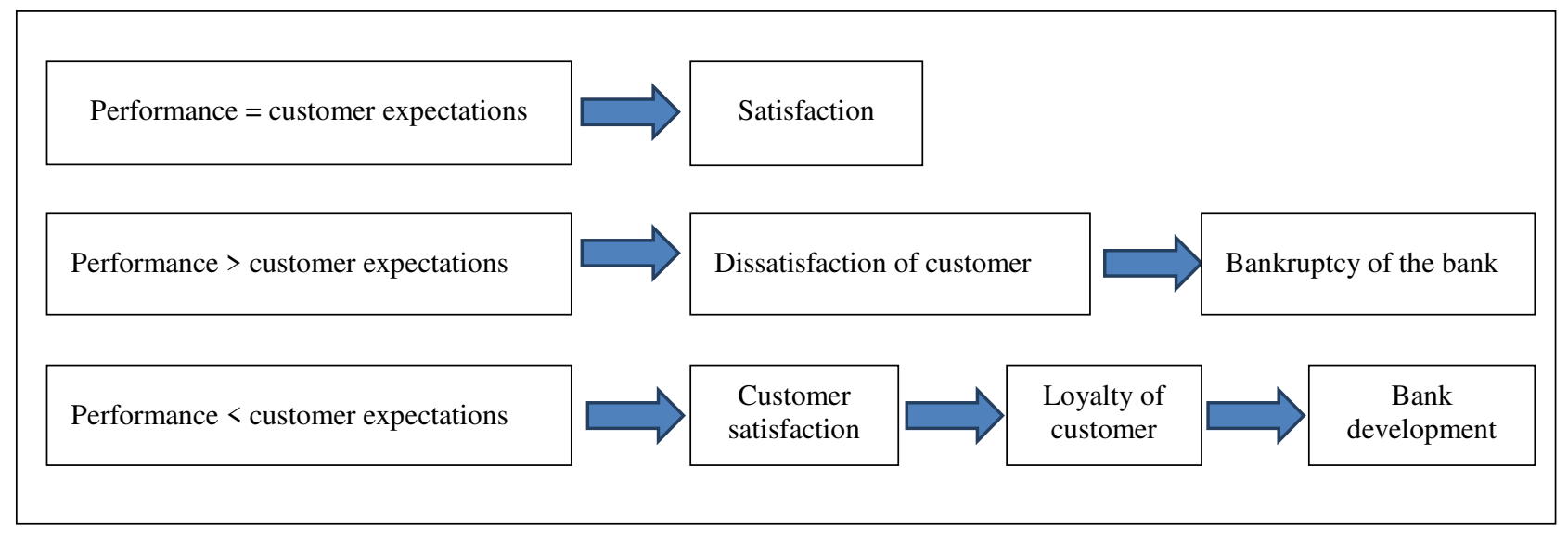

Fig. 2. Different states of the customer satisfaction equation

If the proposed services from bank are equal and/or accompany with customer expectations, they (customers) will be satisfied and in order to get the services, they will return again. Consequently, providing services will continue and continuance of selling will lead to loyalty customer and make him/her happy. This leads to the word-of-mouth recommendation, which is useful to the bank and the continuance of this process increases the bank's share of customers and provides survival and growth of the bank. But if the provided services are customer expectation, two situations will happen:

- non-satisfaction: unsatisfied customer will not be back to the bank again.

- upset customer: according to marketing investigation, this customer, apart from not returning to the bank again, will inform at least 17 persons about poor banking services and will form a negative propaganda against the bank (Mohammad Pourzandi, 2010).

\section{SERVQUAL model}

This model was introduced by Parasouraman et al. in middle of 1980s. In this model, the satisfaction of customers from the quality of proposed services is measured. Some of aspects and dimensions of SERVQUAL model are:

- Tangibles: physical tools, equipment, the apparent of employees and available communication tools.
- Reliability: ability to perform the commitment services by perfect care and trustable.

- Accountability: including encouraging to help customer and providing emergent services.

- Guarantee: including the knowledge and politeness of employees and their abilities to induce the trust to the honesty of services.

- Sympathy: including the specific attention which the firm provides to its special customers with it.

SERVQUAL model consists of two parts:

- First part: measuring the customer expectations.

- Second part: measuring the customer perception.

2.1. The limitations of SERVQUAL model. There is many SERVQUAL model and the most important is that this model is used only to measure the satisfaction of customers with proposed services by firms and it is not favorite procedure for products satisfaction appraisal. This model doesn't take into account the details, but in form of internal and macro considered the satisfaction appraisal.

\section{The loyalty of customer}

Although there are many definitions for the term "loyalty", there are two main approaches: behavioral and attitudinal (Dick, Basu, 2000; Holbrook, Chaudhuri, 1994; Zeithaml, 2001). 
Behavioral approach considers the loyalty as a behavior (Kahn et al., 1986; Ehrenberg et al., 1990) and noticed that re-purchasing is a sign of the loyalty of a customer to a brand. Behavioral loyalty is defined as re-dealing, but this approach cannot distinguish between real and unreal loyalty. The noticeable comment is that merely focusing on behavior (such as re-purchasing) cannot identify the cause of these purchases. It means that only by studying the behavior of customer we cannot find out whether re-purchasing only arise of factors such as easiness or monetary incentives, or the customer really has loyalty (Basu, Dick, 1994). Attitudinal approach says that the attitudes should be considered alongside the behavior in defining the loyalty. But Dick and Basu (1994) argued that attitude scopes toward identifying the determinant factors of customer loyalty in comparison with behavioral scopes are performed as more valuable instruments, so they have more advantages than the behavioral ones.

In today's competitive worlds, the proposed services from rival firms increasingly become alike and it is difficult to surprise the customer by presenting perfectly novel service in the long term, because the most innovative service will be copied quickly from rival side and presented to the market. Hence, investment in customer loyalty domain is effective and beneficial for service firms. Loyalty leads to enhanced profitability through increasing the income, reducing the cost of attracting new customer, reducing the customer sensibility toward price and reduction of the costs of making customer familiar with procedures of firm operation (Beerli et al., 2004). Some of analysis indicates that the cost of attracting a customer is 5 times more that preserving the current one. Working with permanent customer will reduce such costs as the costs of advertisement for finding new customer, creating a new credit, explaining the business processes to new customer and the costs of inefficient transaction during the learning process by customer. But benefit of permanent customer is more than reducing the costs. The more a firm can keep its customers, the more it can earn of it during its lifetime. So, keeping a customer is an important resource for long-term succession of an organization (Mittal \& Lassar, 1998).

3.1. Types of loyalty. In the theory proposed by Dick and Basu (1994), there are three different kinds of loyalty are: exceptional loyalty, hidden loyalty and keeping loyalty.

- Exceptional loyalty refers to the permanent loyalty of customer based on keeping a feature such as relaxing of customer, special offers or the influence of others.

- Hidden loyalty includes high degree of positive customer attitude to the firm, of course not enough that can affect the behavior of customer purchasing.

- The third kind of loyalty is keeping loyalty in which the customer has a lot of preferences and expectations, which influence the purchasing behavior of customers and keep going to be loyal. This loyalty is created when the firm will develop a project of loyalty with long-term profit for customers.

Increasing loyalty can be, according to Oliver (1999), divided into four phases, as it is shown in the picture. These four phases are: recognition, effectiveness, mental, performance.

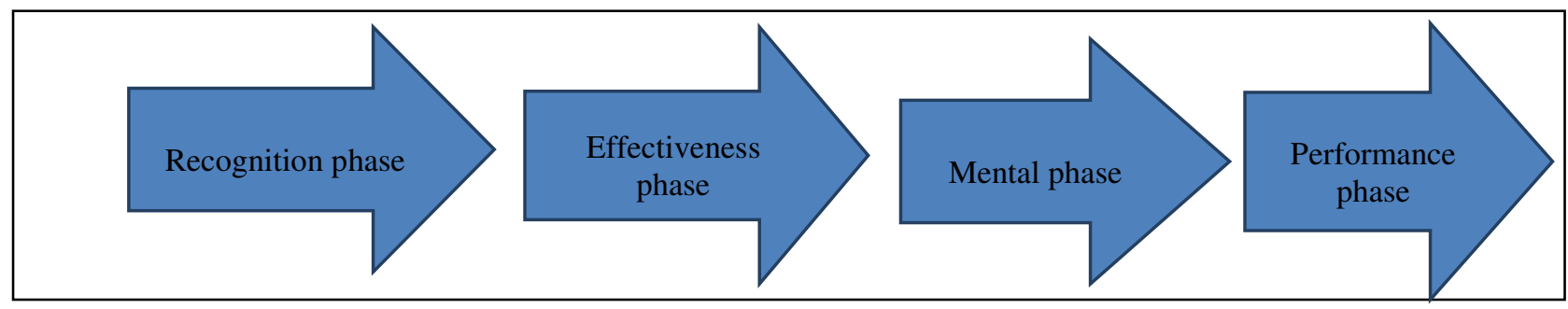

Fig. 3. The levels of increasing loyalty

Source: Oliver, Richard L. (1999).

The first phase is occurred when the customer has obtained the positive knowledge and information about a specific bran, which is led to be preferred to others. Although in recognition loyalty, if the satisfaction is not satisfied, customers tend to change the brand. The next phase is effective one. In this phase, customers will welcome the favorite brand more than before and reach to satisfaction and happiness from their purchase, which has much importance. Effective customers are not so encouraged to deny re-purchasing as customers with cognitive loyalty do. Of course they have no perfect loyalty to the brand. The next step in developing loyalty is a mental phase. This step is resulted of positive mentality and experience of customer when he is going to re-purchase the brand. In this step, the customer directly purchases the brand according to re-purchasing pattern and so has more commitment. Finally, encouraged and commited customers after reaching the mental loyalty are going to re- 
purchase and become the customer of preferred brand. Then, the loyalty of player becomes true and firm will succeeded in keeping the customers (Nategh et al., 2010).

Basically, a firm increases its market share through four ways which are:

1. Increasing rate of attracting new customers of market.
2. Reducing rate of customers who leave the market.

3. Accepting and attracting the customers who have returned from rival's brand.

4. Increasing the maintenance rate of rival's customers who tend to move to the other institution as a result of improving the loyalty (Bahranzadeh et al., 2010).

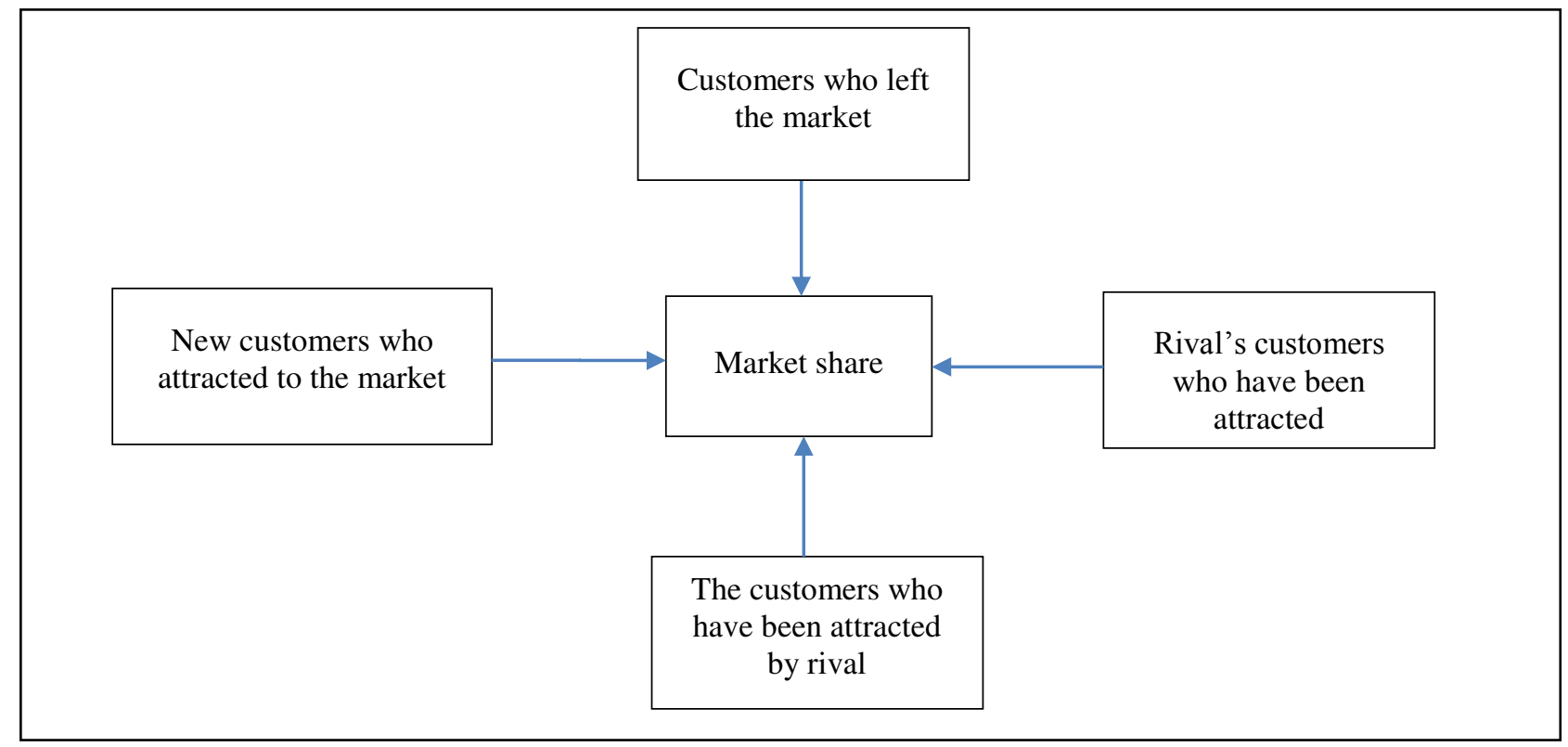

Fig. 4. Link model between loyalty and market share

Source: Rust, R. T., Lemon, K. N., Zeitham V. A. (2004).

\section{Background of conducted researches inside and outside the country}

- Tabatabaei Nasab in his paper titled "Designing and explaining customers' loyalty model in banking industry (case study: Iran banks)" concluded that customer expectations with effective variables of emotional and cognitive processes influence the effectiveness of bank efforts in taking customers' satisfaction attention via improving and promoting their services quality. In loyalty model related to private banks with low performance, customer expectations have inverse relationship with customer satisfaction, but in, exclusive model, private banks have direct relationship with high performance. Also, for developing customer trust, the familiarity variable has positive and direct effect on service (Tabatabaei Nasab, 2009).

- Ranjbaran in the paper titled "The effect of relational marketing foundations on customers' loyalty: comparing governmental and private bank" concluded that in governmental bank, trust, conflict management, commitment and communications, respectively, have effect on customers' loyalty. In regard to governmental bank performance in field of these four variables, it is notable that the best performance of bank was in the field of trust making, but it was moderate in the field of conflict management and communications and commitment and also it was considred moderate in the field of creating loyalty of governmental bank's performance. In private bank, also, the rank of priority of effective variables on customers' loyalty included conflict management, then, trust and commitment with an equal effect, but communications variable did not have significant effect on customers' loyalty in private bank. Private bank performance, also, in the field of trust and conflict management was proper, but in the field of commitment to two prior variables was weaker and in the field of loyalty the performance of private bank was fairly proper (Ranjbaran and et al., 2009).

- Akhavan Sarraf and et al. in their paper titled "Social responsibility position in marketing performance of Mellat Bank" concluded that Mellat bank by placing ethics top and take to account special position for social responsibility in marketing play the roles like creating job, helping to increase the capacity and producing line of industrial sections, introduction itself as green bank, alternating worn car, investing in the field of infrastructures and participating in charity affairs (Akhavan Sarraf and et al., 2009).

- Brain et al. in the paper titled "Trust and ecommerce of customer perception study" 
concluded that as a result of increasing the individuals' trust to e-commerce and e-purchasing experience, the tendency to purchasing will increase, too. Perceived market tendency, site quality, technical trust and labor experiences in web are the effective factors on customers' trust. Verbal positive advertisements, money return and collaboration to known members in business are among important technics in reducing the effectively risk.

- Srini, Srinivasan and et al. in their paper titled "Customer loyalty in e-commerce" concluded that there are eight effective factors on customers' loyalty: 1. Customization, 2. Mutual connection, 3. Friendship and affection, 4. Accuracy and consideration, 5. Unity, 6. Selection right, 7. Convenience, and 8. Validity. Whatever the banks use these factors in providing their e-services the loyalty of customers will increase more than using the bank services. Of the other important results in this research, the positive effect of e-loyalty on positive verbal advertisement and paying money is high.

- Carlos. F., Miguel, J., Raquel. J. in their paper titled "The role of perceived usage capability, customer satisfaction and trust in loyalty to Website" concluded that if the users during the continuous usage of the system understand its usage capability and are satisfied, their trust is increased and, as a result of this process, more loyalty than to the website is created on them.

\section{Reviewing hypotheses}

First hypothesis: there is a significant difference between average hypotheses indexes.

$\mathrm{H} 0$ : there is no a significant difference between average hypotheses indexes.
H1: there is a significant difference between average hypotheses indexes.

Table 1. Results of descriptive statistics (hypotheses indexes)

\begin{tabular}{|l|c|c|c|c|c|}
\hline & Max. & Min. & St. & Mean & Sample size \\
\hline Credit factors & 500 & 2.83 & .42916 & 4.1842 & 400 \\
\hline $\begin{array}{l}\text { Physical } \\
\text { necessities }\end{array}$ & 12.67 & 1.83 & 1.02282 & 4.1392 & 400 \\
\hline Accountability & 5.00 & 2.86 & .39279 & 4.3011 & 400 \\
\hline Trust & 5.00 & 2.60 & .44967 & 4.4025 & 400 \\
\hline Sympathy & 5.00 & 2.00 & .60040 & 3.8450 & 400 \\
\hline
\end{tabular}

Table 2. Average rank of hypotheses indexes

\begin{tabular}{|c|c|c|c|c|}
\hline Trust & Accountability & Credit & $\begin{array}{c}\text { Physical } \\
\text { necessities }\end{array}$ & Sympathy \\
\hline 3.89 & 3.50 & 3.06 & 2.71 & 1.84 \\
\hline
\end{tabular}

Table 3. Results of Friedman test rating (hypotheses indexes)

\begin{tabular}{|c|c|c|c|}
\hline Sample size & k. Oskovar & Freedom degree & Sig. \\
\hline 400 & 405.601 & 4 & 0.001 \\
\hline
\end{tabular}

The obtained results of analyzing data by Friedman test indicated that as the significance of test, that is, 0.001 is less than $\alpha$-test $(0.05), \mathrm{HO}$ is rejected and the claim of study is accepted, it means that there is a significant difference between hypotheses indexes. Mean rate for each of these indexes is indicated based on priority in Table 2 .

Second Hypothesis: there is a significant difference between credit factors indexes.

H0: there is no a significant difference between credit factors indexes.

H1: there is a significant difference between credit factors indexes.

Table 4. Results of descriptive statistics (credit factors)

\begin{tabular}{|l|c|c|c|c|c|}
\hline & Sample size & Mean & St. & Min. & Max. \\
\hline Question 6 & 400 & 3.9695 & 1.04748 & 1.00 & 5.00 \\
\hline Question 7 & 400 & 3.9756 & .85049 & 2.00 & 5.00 \\
\hline Question 22 & 400 & 4.5732 & .62721 & 2.00 & 5.00 \\
\hline Question 27 & 400 & 3.8415 & .79830 & 1.00 & 5.00 \\
\hline Question 37 & 400 & 4.4268 & .70980 & 1.00 & 5.00 \\
\hline Question 10 & 400 & 4.2622 & .82047 & 1.00 & 5.00 \\
\hline
\end{tabular}

Table 5. Results of mean rate of credit factors based on priority

\begin{tabular}{|l|l|}
\hline \multicolumn{1}{|c|}{ Credit factors } & Mean rate \\
\hline 22 - variation of banking services (providing types of services which customers need) & 4.32 \\
\hline 37 - good and enough knowledge and information of bank employee & 4.02 \\
\hline 10 - strength the position of bank in general public and became fame the bank & 3.66 \\
\hline $\begin{array}{l}1 \text { - contact the customers in order to remove possible financial problems (such as charge the issued check accounts in case lack of } \\
\text { deposit) }\end{array}$ & 3.21 \\
\hline 2 - provide information which customers need to help their business and performances. & 3.06 \\
\hline 27 - expand and vary advertisement & 2.73 \\
\hline
\end{tabular}

Table 6. Results of Friedman test (credit factors test)

\begin{tabular}{|c|c|c|c|}
\hline Sample size & k. Oskovar & Freedom degree & Sig. \\
\hline 400 & $118 / 836$ & 5 & 0.002 \\
\hline
\end{tabular}

The obtained results of analyzing data by Friedman test in Table 6 indicated that as the significance of test, that is, 0.002 is less than $\alpha$-test (0.05), 
consequently, $\mathrm{HO}$ is rejected and the claim of study is accepted, which means that there is a significant difference between credit factors indexes. Mean rate for each of these indexes indicated based on priority in Table 5 .

Third hypothesis: there is a significant difference between physical necessities factors indexes.

$\mathrm{H} 0$ : there is no a significant difference between physical necessities factors indexes.

H1: there is a significant difference between physical necessities factors indexe.

Table 7. Results of descriptive statistics (physical necessities factors)

\begin{tabular}{|l|c|c|c|c|c|}
\hline & Sample size & Mean & St. & Min. & Max. \\
\hline Question 23 & 400 & 4.5061 & .63146 & 2.00 & 5.00 \\
\hline Question 28 & 400 & 4.0061 & .87569 & 1.00 & 5.00 \\
\hline Question 29 & 400 & 3.9573 & .88165 & 1.00 & 5.00 \\
\hline Question 31 & 400 & 3.9573 & 4.12437 & 1.00 & 55.00 \\
\hline Question 33 & 400 & 3.8415 & .79830 & 1.00 & 5.00 \\
\hline Question 38 & 400 & 4.2744 & .77004 & 1.00 & 5.00 \\
\hline
\end{tabular}

Table 8. Results of mean rate of physical necessities factors based on priority

\begin{tabular}{|l|c|}
\hline \multicolumn{1}{|c|}{ Physical necessities factors } & Mean rate \\
\hline 23 - developing and expanding e-banking services & 4.49 \\
\hline 38 - good physical necessities and facilities in providing services to customers & 4.08 \\
\hline 28 - attractive and dynamic internet site & 3.39 \\
\hline 29 - direct contact net to the bank for customers (sending messages, SMS, e-mail and .....) & 3.29 \\
\hline 33 - providing the possibility of face to face introducing the services & 3.01 \\
\hline 31 - physical branches vast net & 2.74 \\
\hline
\end{tabular}

Table 9. Results of Friedman test (physical necessities factors test)

\begin{tabular}{|c|c|c|c|}
\hline Sample size & k. Oskovar & $\begin{array}{c}\text { Freedom } \\
\text { degree }\end{array}$ & Sig. \\
\hline 400 & $153 / 436$ & 5 & 0.004 \\
\hline
\end{tabular}

The obtained results of analyzing data by Friedman test in table 9 indicated that as the significance is rejected and $\mathrm{H} 0$ of test, that is, 0.004 is less than $\alpha$ test $(0.05)$ so, consequently, the claim of study is accepted,which means that there significant difference between physical necessities factors indexes. Mean rate each of these indexes is indicated based on priority in Table 8.

Fourth hypothesis: there are significant differences between accountabilityfactors indexes.

H0: there is no a significant difference between accountability factors indexes.

$\mathrm{H} 1$ : there is a significant difference between accountability factors indexes.

Table 10. Results of descriptive statistics (accountability factors)

\begin{tabular}{|l|c|c|c|c|c|}
\hline & Sample size & Mean & St. & Min. & Max. \\
\hline Question 1 & 5.00 & 1.00 & $0 / 79858$ & 4.2927 & 400 \\
\hline Question 3 & 5.00 & 1.00 & $0 / 91431$ & 4.0671 & 400 \\
\hline Question 4 & 5.00 & 2.00 & $0 / 88464$ & 4.1220 & 400 \\
\hline Question 11 & 5.00 & 2.00 & $0 / 85634$ & 4.2134 & 400 \\
\hline Question 32 & 5.00 & 1.00 & $0 / 64110$ & 4.4939 & 400 \\
\hline Question 34 & 5.00 & 1.00 & $0 / 74758$ & 4.2805 & 400 \\
\hline
\end{tabular}

Table 11. Results of average of physical necessities factors based on priority

\begin{tabular}{|l|c|}
\hline \multicolumn{1}{|c|}{ Accountability factors } & Mean rate \\
\hline 35 - quick providing banking services & 4.64 \\
\hline 32 - developing e-banking and providing the possibility of presenting types of banking services everywhere and anytime that customer needs & 4.48 \\
\hline 1 - verity of banking services (providing types of services that customer needs. & 4.03 \\
\hline 34 - easy providing bank services & 3.96 \\
\hline $\begin{array}{l}11 \text { - creating a network so that customers by referring to any branch of bank in any point of country could be identified and their records } \\
\text { would be clear. }\end{array}$ & 3.79 \\
\hline 4 - being low the rate of granting facilities & 3.63 \\
\hline 1 - providing bank services in low commission rate & 3.46 \\
\hline
\end{tabular}


Table 12. Results of Friedman test (accountability factors)

\begin{tabular}{|c|c|c|c|}
\hline Sample size & k. Oskovar & Freedom degree & Sig. \\
\hline 400 & 57.056 & 6 & 0.002 \\
\hline
\end{tabular}

The obtained results of analyzing data by Friedman test in Table 12 indicated that as the significance is rejected and $\mathrm{H} 0$ of test, that is, 0.002 is less than $\alpha$ test (0.05), consequently, the claim of study is accepted, which means that there is a significant difference between accountability factors indexes. Mean rate for each of these indexes is indicated based on priority in Table 11 .

Fifth hypothesis: there are significant differences between trust factors indexes.

$\mathrm{HO}$ : there is no a significant difference between trust factors indexes.

H1: there is a significant difference between trust factors indexes.

Table 13. Results of descriptive statistics (trust factors)

\begin{tabular}{|l|c|c|c|c|c|}
\hline & Sample size & Mean & St. & Max. \\
\hline Question 2 & 400 & 4.1035 & $4 / 3171$ & 54.00 \\
\hline Question 24 & 400 & $0 / 85354$ & $4 / 2500$ & 5.00 \\
\hline Question 25 & 400 & $0 / 71335$ & $4 / 4817$ & 2.00 \\
\hline Question 26 & 400 & $0 / 60412$ & $4 / 6463$ & 2.00 & 2.00 \\
\hline Question 36 & 400 & $0 / 57124$ & $4 / 6524$ & 3.00 \\
\hline Question 2 & 400 & 4.1035 & $4 / 3171$ & 5.00 & 5.00 \\
\hline
\end{tabular}

Table 14. Results of mean rate of trust factors based on priority

\begin{tabular}{|l|c|}
\hline \multicolumn{1}{|c|}{ Trust factors } & Mean rate \\
\hline 36- good contact of employee & 3.42 \\
\hline 26- high benefit of funding deposits in contrast to other banks & 3.41 \\
\hline 25- low rate of granting facilities & 3.10 \\
\hline 24- low rate of providing bank services commission & 2.65 \\
\hline 2- granting presents and awards to the customers who have regular connecting to the bank & 2.42 \\
\hline
\end{tabular}

Table 15. Results of Friedman test (trust factors)

\begin{tabular}{|c|c|c|c|}
\hline Sample size & k. Oskovar & Freedom degree & Sig. \\
\hline 400 & 89.359 & 4 & 0.001 \\
\hline
\end{tabular}

The obtained results of analyzing data by Friedman test in Table 15 indicated that as the significance of test that is, 0.001 is less than $\alpha$-test $(0.05), \mathrm{H} 0$ is rejected and the claim of study is accepted, which means that there is a significant difference between trust factors indexes. Mean rate for each of these indexes is indicated based on priority in Table 14.

Sixth hypothesis: there are significant differences between sympathy factors indexes.

H0: there is no a significant difference between sympathy factors indexes.

H1: there is a significant difference between sympathy factors indexes.

Table 16. Results of descriptive statistics (sympathy factors)

\begin{tabular}{|l|c|c|c|c|c|}
\hline & Sample size & Mean & St. & Min. & Max. \\
\hline Question 5 & 400 & 3.9268 & $0 / 94357$ & 1.00 & 5.00 \\
\hline Question 6 & 400 & 3.9695 & $1 / 04748$ & 1.00 & 5.00 \\
\hline Question 8 & 400 & 3.4390 & $1 / 11979$ & 1.00 & 5.00 \\
\hline Question 9 & 400 & $3 / 8293$ & $0 / 95680$ & 1.00 & 5.00 \\
\hline Question 30 & 400 & $4 / 0244$ & $0 / 93304$ & 1.00 & 5.00 \\
\hline Question 5 & 400 & 3.9268 & $0 / 94357$ & 1.00 & 5.00 \\
\hline
\end{tabular}

Table 17. Results of mean rate of sympathy factors based on priority

\begin{tabular}{|l|c|}
\hline \multicolumn{1}{|c|}{ Sympathy factors } & Mean rate \\
\hline 30- granting presents and awards to good pay, loyal and ... customers & 3.29 \\
\hline $\begin{array}{l}\text { 6- contact with customers to remove the possible financial problems (such as charging the account of issued checks in case of deficit of } \\
\text { deposit) }\end{array}$ & 3.20 \\
\hline 5- sending postal card and presents in special situation to customers & 3.11 \\
\hline 9- receiving views and ideas of customers in case of the services which bank is going to provide & 2.94 \\
\hline $\begin{array}{l}\text { 8- Supplying other services that customers need (except banking services) from other resources and providing insurance services or } \\
\text { reserved flight ticket and ....) }\end{array}$ & 2.46 \\
\hline
\end{tabular}


Table 18. Results of Friedman test (sympathy factors)

\begin{tabular}{|c|c|c|c|}
\hline Sample size & k. Oskovar & Freedom degree & Sig. \\
\hline 400 & 39.341 & 4 & 0.003 \\
\hline
\end{tabular}

The obtained results of analyzing data by Friedman test in table 18 indicated that as the significance of test, that is, 0.003 is less than $\alpha$-test $(0.05), \mathrm{H} 0$ is rejected and the claim of study is accepted, which means that there is a significant difference between sympathy factors indexes. Mean rate for each of these indexes is indicated based on priority in Table 17.

Seventh hypothesis: there are significant differences between losing bank customers factors indexes.

H0: there is no a significant difference between losing bank customers factors indexes.

H1: there is no significant difference between loosing bank customers factors indexes.

Table 19. Results of descriptive statistics pertaining to factors of loosing bank customers

\begin{tabular}{|l|c|c|c|c|c|}
\hline & Sample size & Mean & St. & Min. & Max. \\
\hline Question 12 & 400 & 4.0100 & .83765 & 2.00 & 5.00 \\
\hline Question 13 & 400 & 3.3350 & .97989 & 1.00 & 5.00 \\
\hline Question 14 & 400 & 4.2200 & .87389 & 1.00 & 5.00 \\
\hline Question 15 & 400 & 4.0850 & .84828 & 1.00 & 5.00 \\
\hline Question 16 & 400 & 4.1825 & .93883 & 1.00 & 5.00 \\
\hline Question 17 & 400 & 3.7475 & .98038 & 1.00 & 5.00 \\
\hline Question 18 & 400 & 4.3800 & .92614 & 1.00 & 5.00 \\
\hline Question 19 & 400 & 4.1225 & .75094 & 2.00 & 5.00 \\
\hline Question 20 & 400 & 3.9975 & .92717 & 1.00 & 5.00 \\
\hline Question 21 & 400 & 3.5325 & 1.11447 & 1.00 & 5.00 \\
\hline
\end{tabular}

Table 20. Mean rate of most important factors of loosing bank customers based on priority

\begin{tabular}{|l|c|}
\hline \multicolumn{1}{|c|}{ Factors of loosing bank customers } & Mean rate \\
\hline 18- improper behavior of employee to customers & 6.97 \\
\hline 14- not performing according to prior promises to customers & 6.39 \\
\hline 16- low quickness of providing services to customers & 6.31 \\
\hline 19- lack of enough information of employee in guiding and providing services to customers & 5.92 \\
\hline 15- not being honest in customers problem solving & 5.84 \\
\hline 12- improper physical equipment and necessities for providing services to customers & 5.61 \\
\hline 20- non understanding the situations and special needs of customers and not pay attention to them & 5.56 \\
\hline 17- not informing the customers about exact time of providing inquiry services & 4.70 \\
\hline 21- improper bank work time & 4.25 \\
\hline 13- improper brochures and posters and advertising panels for introducing the bank & 3.46 \\
\hline
\end{tabular}

Table 21. Results of Friedman test (factors of loosing bank customers)

\begin{tabular}{|c|c|c|c|}
\hline Sample size & k. Oskovar & Freedom degree & Sig. \\
\hline 400 & 603.335 & 9 & .015 \\
\hline
\end{tabular}

The obtained results of analyzing data by Friedman test in Table 21 indicated that as the significance of test, that is, 0.015 is less than $\alpha$-test $(0.05), \mathrm{H} 0$ is rejected and the claim of study is accepted, which means that there is significant difference between sympathy factors indexes. Mean rate for each of these indexes is indicated based on priority in Table 20.

According to compiled information and analyzing them, the following comments can be mentioned as the most important:

* The factors of trust, accountability, credit, respectively, have the most importance in order of priority.

Table 22. Results of significance between hypothesis and each of investigation hypothesis

\begin{tabular}{|l|l|c|c|c|c|}
\hline Hypothesis & \multicolumn{1}{|c|}{ Investigation hypothesis } & $\begin{array}{c}\text { Friedman test } \\
\text { (k.Oskovar) }\end{array}$ & $\begin{array}{c}\text { Freedom } \\
\text { degree }\end{array}$ & Sig. & Hypothesis result \\
\hline Fist & Between investigation hypothesis indexes & 405.601 & 4 & 0.001 & Accepted \\
\hline Second & There is significant difference between credit factors indexes & 118.836 & 5 & 0.002 & Accepted \\
\hline Third & $\begin{array}{l}\text { There is significant difference between physical necessities } \\
\text { factors indexes }\end{array}$ & 153.436 & 5 & 0.004 & Accepted \\
\hline Forth & $\begin{array}{l}\text { There is significant difference between accountability factors } \\
\text { indexes }\end{array}$ & 57.056 & 6 & 0.002 & Accepted \\
\hline
\end{tabular}


Table 22 (cont.). Results of significance between hypothesis and each of investigation hypothesis

\begin{tabular}{|l|l|c|c|c|c|}
\hline Hypothesis & \multicolumn{1}{|c|}{ Investigation hypothesis } & $\begin{array}{c}\text { Friedman test } \\
\text { (k.Oskovar) }\end{array}$ & $\begin{array}{c}\text { Freedom } \\
\text { degree }\end{array}$ & Sig. & Hypothesis result \\
\hline Fifth & There is meaningful difference between trust factors indexes & 89.359 & 4 & 0.001 & Accepted \\
\hline Sixth & $\begin{array}{l}\text { There is meaningful difference between sympathy factors } \\
\text { indexes }\end{array}$ & 39.341 & 4 & 0.003 & Accepted \\
\hline Seventh & $\begin{array}{l}\text { There is meaningful difference between loosing bank customers } \\
\text { factors indexes }\end{array}$ & 603.335 & 9 & 0.015 & Accepted \\
\hline
\end{tabular}

Table 23. Identifying the most priority hypothesis factors

\begin{tabular}{|l|l|}
\hline \multicolumn{1}{|c|}{ Factors } & \multicolumn{1}{c|}{6 identifying the most priority factors } \\
\hline Credit factors & Variety of banking services (providing types of services that customers need) \\
\hline Physical necessities factors & Developing and Expanding e-banking services \\
\hline Accountability factors & Speed in providing bank services \\
\hline Trust factors & Quality of employee behavior and contact \\
\hline Sympathy factors & Granting presents and awards to good pay, loyal and customers \\
\hline
\end{tabular}

\section{Conclusion}

Customers and consumers are always seeking for suppliers who provide them with much better goods or services. Many evidences and documents indicate that in today compete world, exploring the needs and understanding what customers want and satisfying them before the rival does is a basic condition for enterprises to get success. Hence, organizations and enterprises are striving to reach the excellent positions than their rivals through attaining the unique advantages. Among this, financial industry is one of the most competitive industries in our country in which the importance of keeping and making customers and beneficiaries satisfied is the most important subject. On the other hand, it's not so long that the concept of making customers to be loyal has become considerable and popular subject among the marketing experts (Nunes \& Dreze, 2006; Uncles, 2006; Rohem, 2006). One real loyalty or loyal-making program is beyond discount and like it and including any incentive that the program manager provide around lifestyle, purchasing options, incentive programs and ... of individuals and their families to obtain their satisfaction along with their shares from their businesses. There are different programs and tools for making satisfaction and increasing customers' loyalty. The tools are as follows: personalizing services, complaints and recommendations system, tracking system of interactions with customers, special services, rewards granting, holding celebrations, granting financial and non-financial scores, triggering call center and possibility of interaction to organization, using the information bank of customers and creating customers club.

\section{Important recommendations for marketing}

- Cut off the marketing costs, which cause the pale presence in market, reduction of market share, income and profit.

- Consider marketing expenditure as funding not cost.

- Revise your marketing strategy.
- Change marketing strategy for problematic situations.

- Keeping the existing customers and emphasis and focus on adding value.

- Set and promote programs for loyal customers.

- Granting special advantage and bonus to permanent customers, so that they repeat their purchase.

- Creating incentive to buy more and continuously, specifically in crisis and inflation circumstances

- Providing special, extra and attractive services to the current customer.

- Training the staff about the techniques to be accountable to different types of current customers' needs.

- Keep in touch with current customers and ask them for introducing new customers.

- Prevent the ineffective and useless advertisement and marketing.

- Use the interactive communication instruments.

- Understand your customers over the time.

- Identify your customers' preferences and interests.

- Show them that you understand them through replying their needs.

- All of marketing affairs should be traceable.

- Identified advertisements

- Communication

- Make sure in which cases marketing expenditures are.

- Remove them, if they don't make income

- Do more and more vast, if they are profitable

- Focus on goods and services, which require less budget.

- Work with customers who are financially more reliable.

- Current customers' acceptance and compliments are very effective (recommendation and acceptance of satisfied customers).

- Providing presents and awards is an incentive for customers who recommend you and are reference, is less but effective cost. 


\section{References}

1. Akhavan Saraf, A. (2009). The position of social responsibility in marketing performance of Mellat Bank. The first conference of banking services marketing.

2. Akhavan Sarraf, A. (2009). Social responsibility place in marketing performance of Mellat Bank. $1^{\text {st }}$ Conference for bank services marketing.

3. Bahranzadeh, Mohammad Mahdi et al. (2010). Identifying and rating the influential factors on loyalty of customers in private banks in Khoozestan Province. Second international conference of financial services marketing.

4. Beerli, A., Martin, J. D., Quintana, A. (2004). A Model of Customer Loyalty in the Retail Banking Market. European Journal of Marketing, 38(1-2), 253-275.

5. Brain. J. C. T., Han, Y. (2003). Trust and e-commerce: a study of consumer perceptions. Electronic Commerce Research and Applications, 2, 203-215.

6. Carlos, F., Miguel, G., Raquel, G. (2006). The role played by perceived usability, satisfaction and consumer trust on website loyalty. Information \& Management, 43, 1-14.

7. Chaudhuri, A., Holbrook, M. B. (2001). The Chain of Effects From Brand Trust and Brand Affect to Brand Performance: The Role of Brand Loyalty. Journal of Marketing, 65(2), 81-93.

8. Davis, F. L., Moutinho, B. (1996). Atm User Attitudes: A Neural Network Analysis. Marketing Intelligence and Planning, 14(2), 26-32.

9. Dick, A. S., Basu, K. (1994). Customer Loyalty: Toward an Integrated Conceptual Framework. Journal of the Academy of Marketing Science, 22(2), 99-113.

10. Ehrenberg, A. S. C., Goodhardt, G. J., Barwise, T. P. (1990). Double Jeopardy Revisited. Journal of Marketing 54(3), 82-91.

11. Kahn, B. E., Kalwani, M. U., Morrison, D. G. (1986). Measuring Variety - Seeking and Reinforcement Behaiors Using Panel Data. Journal of Marketing Research, 23(2), 89-100.

12. Mittal, Banwari, Lassar, Walfried. (1998). Why Customer Switch? The Dynamics of Faction versus Loyalty. Journal of Service Marketing, 12(3).

13. Mohammad Pourzarandi, Hossein et al. (2010). Customer orientation is the origin of innovation in banking service. The second international conference of financial services marketing.

14. Nategh, Mohammad et al. (2010). Developing bank customers club: a competitive instrument to attract and loyalty of customers.

15. Nunes, J., Dreze, X. (2006). Your Loyalty Program is Betraying You. Harward Business Review.

16. Oliver, Richard L. (1999). Whence Consumer Loyalty? Journal of Marketing, 63(4), 33-44.

17. Ranjbarian, B. (2009). The effect of relational marketing foundations on customers' loyalty: comparing governmental and private bank. Commercial Management publication, $1^{\text {st }}$ version, No. 2.

18. Roehm, M., Pullins, E., Roehm, H. (2006). Designing Loyalty - Building Programs for Packaged Goods Brands. Journal of Marketing Research, 39(2), 102-130.

19. Shahrajabian, N. (2009). Novel strategies in banking services marketing. The first conference of banking services marketing.

20. Srinis, S., Rolph, A., Kishore, P. (2002). Customer, Loyalty in e-commerce: an exploration of its an tecedents and Consequences. Journal of Retailing, 78, 41-50.

21. Tabatabaeinasab, M. (2009). Designing and explaining customers' loyalty model in banking industry (case study: Iran Banks). $1^{\text {st }}$ International Conferences for Bank Services Marketing

22. Zeithaml, V. A. (2000). Service Quality, Profitability and the Economic Worth of Customers: What We Know and What We Need to Learn. Journal of the Academy of Marketing Science, 28(1), 67-85. 